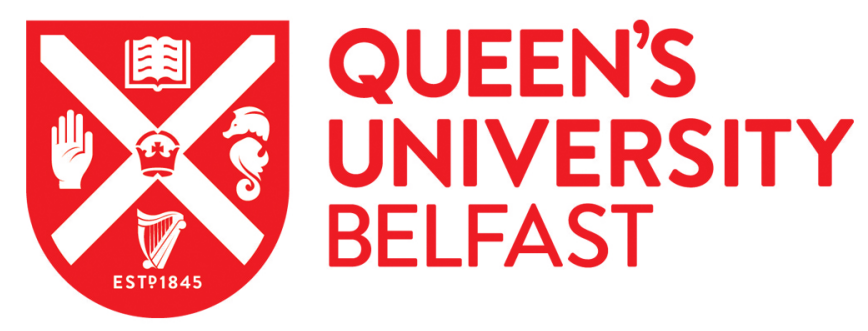

\title{
Evidence-based systematic review of cognitive rehabilitation, emotional, and family treatment studies for children with acquired brain injury literature: From 2006 to 2017
}

Laatsch, L., Dodd, J., Brown, T., Ciccia, A., Connor, F., Davis, K., Doherty, M., Linden, M., Locascio, G.,

Lundine, J., Murphy, S., Nagele, D., Niemeier, J., Politis, A., Rode, C., Slomine, B., Smetana, R., \& Yaeger, L. (2020). Evidence-based systematic review of cognitive rehabilitation, emotional, and family treatment studies for children with acquired brain injury literature: From 2006 to 2017. Neuropsychological Rehabilitation, 30(1), 130161. https://doi.org/10.1080/09602011.2019.1678490

Published in:

Neuropsychological Rehabilitation

Document Version:

Peer reviewed version

Queen's University Belfast - Research Portal:

Link to publication record in Queen's University Belfast Research Portal

Publisher rights

(c) 2019 Informa UK Limited, trading as Taylor \& Francis Group.

This work is made available online in accordance with the publisher's policies. Please refer to any applicable terms of use of the publisher.

\section{General rights}

Copyright for the publications made accessible via the Queen's University Belfast Research Portal is retained by the author(s) and / or other copyright owners and it is a condition of accessing these publications that users recognise and abide by the legal requirements associated with these rights.

\section{Take down policy}

The Research Portal is Queen's institutional repository that provides access to Queen's research output. Every effort has been made to ensure that content in the Research Portal does not infringe any person's rights, or applicable UK laws. If you discover content in the Research Portal that you believe breaches copyright or violates any law, please contact openaccess@qub.ac.uk. 
Neuropsychological Rehabilitation, published 02/01/2020

\section{Running Head: $A B I$ children treatment}

\section{An Evidence-Based Systematic Review of Cognitive Rehabilitation, Emotional, and Family Treatment Studies for Children with Acquired Brain Injury}

Linda Laatsch Ph.D. ${ }^{1}$, Jonathan Dodd Psy.D. ${ }^{2}$, Tanya Brown Ph.D. ${ }^{3}$, Angela Ciccia Ph.D. ${ }^{4}$, Felicia Conner Psy.D. ${ }^{5}$, Kim Davis Ph.D. ${ }^{6}$, Meghan Doherty OTD, Mark Linden Ph.D. ${ }^{8}$, Gianna Locascio Psy.D. ${ }^{9}$, Jennifer Lundine Ph.D. ${ }^{10}$, Drew Nagele Ph.D. ${ }^{11}$, Janet Neimeier Ph.D. ${ }^{12}$, Adam Politis MS ${ }^{13}$, Catrin Rode Ph.D. ${ }^{14}$, Beth Slomine Ph.D. ${ }^{15}$, Racheal Smetana $M A^{16}$, Samantha Murphy BA ${ }^{17}$, Lauren Yaeger $\mathrm{MA}^{18}$

Affiliations: ${ }^{1}$ Univeristy of Illinois College of Medicine (retired), ${ }^{2}$ WellStar Medical Group, ${ }^{3}$ Mayo Clinic, ${ }^{4}$ Case Western Reserve University, ${ }^{5}$ Rusk Rehabilitation, NYU, ${ }^{6}$ Baylor College of Medicine, ${ }^{7}$ Saint Louis University, ${ }^{8}$ Queen's University Belfast, ${ }^{9}$ New York University, ${ }^{10}$ Ohio State University, ${ }^{11}$ Beechwood NeuroRehab, ${ }^{12}$ Atrium Health System,

${ }^{13}$ National Institutes of Health Clinical Center, ${ }^{14}$ University of Oregon, ${ }^{15}$ Johm Hopkins University School of Medicine, ${ }^{16}$ Adler University, ${ }^{17}$ Southern Illinois University, ${ }^{18}$ Washington University at St. Louis School of Medicine 


\title{
Neuropsychological Rehabilitation, published 02/01/2020
}

\begin{abstract}
This paper updates guidelines of effective treatments for children with acquired brain injury $(A B I)$ by including new evidence found in recent years and by building upon evidence presented in 2007. A systematic search was conducted for articles published from 2006-2017. Full manuscripts describing treatments of children (post-birth to 18) with acquired brain injury were included if study was published in peer-reviewed journals and written in English. Two independent reviewers and a third, if conflicts existed, evaluated the methodological quality of studies with an Individual Study Review Form and a Joanna Briggs Institute (JBI) Critical Appraisal Checklist. Strength of study characteristics was used in development of practice guidelines. Fifty-six peer-reviewed articles, including 28 Class I studies, were included in the final analysis. Established guidelines for writing practice recommendations were used and 22 practice recommendations were written with details of potential treatment limitations. There was strong evidence for family/caregiver-focused interventions, as well as direct interventions to improve attention, memory, executive functioning, and emotional/behavioral functioning. A majority of the practice standards and guidelines provided evidence for the use of technology in delivery of interventions, representing an important trend in the field.
\end{abstract}

Key Words: acquired brain injury, rehabilitation, cognitive rehabilitation, evidencebased systematic review, children 


\section{Neuropsychological Rehabilitation, published 02/01/2020}

Abbreviations: $A B I=a c q u i r e d$ brain injury, $A C R M=A m e r i c a n$ Congress of Rehabilitation Medicine, ACT=Acceptance and Commitment Therapy, Amsterdam Memory and Attention Training for Children=Amat-c, BRIEF=Behavior Rating Inventory of Executive Function, BRIEF-MI=The Behavior Rating Inventory of Executive Function Metacognitive Index, CAPS=Counselor Assisted Problem-solving, CBT=cognitive behavior therapy, $\mathrm{COPM}=$ Canadian Occupational Performance Measure, $\mathrm{CO}-\mathrm{OP}=$ Cognitive Orientation to daily Occupational Performance, $\mathrm{CRP}=$ Cognitive Remediation Program, EBR=EvidenceBased Review, FPS = Family Problem-solving, IRC= Internet Resource Comparison, SSTP=Stepping Stones Triple P, SMART=Strategic Memory Advanced Reasoning Training, $\mathrm{TBI}=$ traumatic brain injury, TOPS= Teen Online Problem-solving, $\mathrm{TOPS}-\mathrm{TO}=$ Teen Online Problem-solving-Teens Only, WM=Working Memory 


\section{Neuropsychological Rehabilitation, published 02/01/2020}

\section{Introduction}

In 2007 a diverse group of treatment providers, members of the American Congress of Rehabilitation Medicine (ACRM), published an Evidence-Based Review (EBR) evaluating the effectiveness of cognitive rehabilitation and behavioral treatments for children with acquired brain injury $(A B I)^{[1]}$. The present EBR updates this evidence related to effective treatment published over the past decade. As in the initial review, a multidisciplinary group including direct treatment providers and researchers conducted the EBR, employing analogous data search and evaluation components of the study.

In the initial study by Laatsch et al. ${ }^{[1]} 28$ studies met criteria for full evaluation after a search of peer-reviewed English-language publications from 1980 to 2006. Two practice guidelines were developed: one practice guideline for involving family members as active treatment providers and one practice option for attention remediation.

Nevertheless, there continues to be great need for the identification of effective treatments for rehabilitation of children following ABI. For example, Fuentes et al. ${ }^{[2]}$ conducted a longitudinal cohort study examining the unmet needs of children following traumatic brain injury (TBI) during the first two years after injury. They reported that children with brain injuries generally have persistent, unmet functional needs across multiple domains and should be monitored closely for unresolved functional impairments. Increased time post-injury and a diagnosis of complicated mild TBI were 


\section{Neuropsychological Rehabilitation, published 02/01/2020}

associated with unmet therapy needs, particularly in the areas of cognition and communication.

Since 2007 there has been a consistent accumulation of studies examining treatments hypothesized to be effective in children with $A B{ }^{[3,4]}[5,6]$. Most reviews commented on the limited number of studies and scarcity of Class I studies. Recently, Retsch et al. ${ }^{[4]}$ reviewed the literature (from 1966-current) to determine what components of cognitive rehabilitation interventions were effective in children with $A B I$. Twenty studies were found to meet their criteria, but the authors did not classify the studies using EBR techniques. Instead, they summarized intervention details, intervention settings, and intervention frequency. Results were rated according to improvements in level of function, academic outcomes, and psychosocial functioning. All of the Resch et al. ${ }^{[4]}$ studies, which met our inclusion and exclusion criteria, are included in this EBR.

Linden, Glang, and McKinlay ${ }^{[7]}$ performed a systematic review and meta-analysis, using randomized control trial (RCT) class I studies, to examine educational interventions for children with $\mathrm{ABI}$. While three studies met their meta-analysis criteria, there were no significant differences between educational intervention and control conditions on academic achievement. Even though many interventions have been developed, researchers are generally not measuring the impact of these interventions on academic 


\section{Neuropsychological Rehabilitation, published 02/01/2020}

outcome.

Thus, despite the acceleration of research regarding treatment interventions for children with $\mathrm{ABI}$, there remains a significant need to improve and develop specific treatments. Reviewers' purpose is to summarize and report on a full range of cognitive rehabilitation and emotional/behavioral treatments published between 4/2006-12/2017 [8]. This study identifies effective cognitive rehabilitation and emotional treatments for children with $\mathrm{ABI}$ and supports the evolution of practice guidelines to assist treatment providers, educators, and family.

\section{Methods}

Search strategy: This systematic review is reported in accordance with the PRISMA Systematic Review and Meta-Analyses guidelines ${ }^{[9]}$. The published literature was searched stepwise using strategies created by a medical librarian for the concepts of rehabilitation, children, and $\mathrm{ABI}$. Key words were implemented in five databases (Figure I). A total of 1088 studies were found. Two studies were added via hand search. Twentyeight duplicates were found using an automatic duplication finder and an additional eight duplicate records were discovered manually and removed leaving 1054 unique citations in the project library.

Inclusion and exclusion criteria: 1) Publication: full manuscripts (abstracts, brief reports not included) published from 4/2006-12/2017; 2) Population: TBI, concussion, brain 


\section{Neuropsychological Rehabilitation, published 02/01/2020}

trauma, brain tumor and associated treatments excluding stroke, epilepsy, cerebral palsy, malaria, brain infections; 3) Age: Post-birth through age 18 years; 4) Intervention: Documented in the paper, can include those provided by therapist or technology. Treatment domains used were, attention \& memory, comprehensive, emotional control and CBT, executive functioning, family/caregiver, language/academic, motor, technology; 5) Outcome: must be measured systematically and empirically; 6) Language: English.

Data extraction: The first two authors examined and agreed upon each unique citation for inclusion/exclusion criteria, after which 100 articles remained. Based upon the specifics of the intervention, these articles were grouped into eight treatment domains. Because these articles encompassed a wider range of interventions than those included in the 2007 study, three new treatment domains were introduced, including Technology, Family/Caregiver, and Motor. Technology interventions were identified when the majority of the treatment involved computer-based therapy with limited faceto-face therapist intervention. If intervention focused on motor-related cognitive skills, it was placed in the Motor domain. Similarly, if treatment focused on providing behavioral and emotional support to family/caregivers, the citation was placed in the Family/Caregiver domain. The Emotional Control/CBT domain incorporated both emotional control treatment and cognitive behavior therapy (CBT). The Comprehensive domain included studies that integrated multiple modalities of rehabilitation. 


\section{Neuropsychological Rehabilitation, published 02/01/2020}

Sixteen reviewers, two for each domain, proceeded to review the full studies. Reviewers confirmed that each study met established inclusion/exclusion criteria. This step reduced the number of qualifying studies to 56 (Table II). Since no studies in the language/academic domain met inclusion criteria, no articles were classified from this domain.

Classification of Studies: This step was conducted using DistillerSR, a web-based systematic review tool ${ }^{[10]}$. Using DistillerSR assured that review and classification of qualifying studies were performed independently. The first author provided support and monitored the online progress of the reviewers. Reviewers completed two standardized forms for each article in their treatment domain: the Individual Study Review Form ${ }^{[11]}$ and a JBI Critical Appraisal Checklist to assist with detection of study bias and evaluate quality of evidence ${ }^{[12]}$. Reviewers classified each study as providing Class I, II, or III evidence based on the Individual Study Review and JBI forms; Class I evidence was assigned to prospective, properly designed, randomized, controlled trials, Class II evidence to prospective, non-randomized cohort studies, retrospective non-randomized case control studies, or clinical series with well-designed controls, and Class III evidence to clinical series without concurrent controls and case studies.

DistillerSR filtered the individual responses from the two treatment domain reviewers. The first two authors examined the data for conflicts in the classification of studies and 


\section{Neuropsychological Rehabilitation, published 02/01/2020}

quality of evidence. One of the two first authors communicated with both reviewers in a given domain to discuss identified conflicts and act as a third reviewer when required. All conflicts were resolved and the classification results are provided in Table II.

Practice recommendations were developed using the standards proposed in the Clinical Practice Guideline Process Manual ${ }^{[13]}$ and the adult cognitive rehabilitation EBR by Cicerone et al. ${ }^{[11]}$ (Table III). Evidence based treatment recommendations were developed by the reviewers using specific qualifications: 1) A practice standard required strong evidence from at least one Class I study with additional support from a Class II or III study. 2) A practice guideline required a well-designed Class II study or Class I study/studies with methodological limitations. 3) A practice option required evidence from weaker Class I or II studies that address the effectiveness of the treatment directly and could be considered an option while treating children with $A B I$.

\section{Results}

Attention and Memory: Twelve studies evaluating attention and memory interventions were reviewed: 4 Class I, 2 Class II, and 6 Class III.

The first Class I study was a multicenter, randomized clinical trial ${ }^{[14]}$ evaluating the Cognitive Remediation Program (CRP) of massed practice, strategy acquisition, and cognitive behavioral interventions. 161 children with attentional disturbance secondary to ABI were assigned to a 20-session CRP or wait list control group. The CRP group had 


\section{Neuropsychological Rehabilitation, published 02/01/2020}

statistically significant improvements in academic achievement and parent-reported attention compared to controls, and acquired significantly more metacognitive and learning strategies. There were no significant differences on neuropsychological tests, despite trends in the CRP group.

An additional class I study ${ }^{[15]}$ examined long-term effects of an attention and memory training program for children with $A B I$ six months after an initial study ${ }^{[16]}$ in which 38 children were randomly assigned to treatment or control groups. Children in the treatment group received the Amsterdam Memory and Attention Training for Children (Amat-c), a multi-component intervention involving process-specific training and metacognitive strategy training supervised by a coach, with weekly feedback meetings with a psychologist or special education teacher. As noted immediately after treatment, at six-month follow-up, participants in the treatment group maintained significant improvements on neuropsychological measures of sustained attention, selective attention, and verbal and visual memory compared to control participants.

In a single-blinded Class I pilot study ${ }^{[17]}, 20$ adolescents with a gist processing deficit after mild, moderate, or severe TBI were pseudo-randomized into a Strategic Memory Advanced Reasoning Training (SMART) or control group of memory strategy training. The intervention group had statistically significant improvements in abstraction, interpretation, and recall. 


\section{Neuropsychological Rehabilitation, published 02/01/2020}

The final Class I randomized controlled trial included 17 children after mild, moderate, or severe $\mathrm{TBI}^{[18]}$ with self- or parent-reported attentional deficits. Participants were randomly assigned to the Ready! Set? Let's Train! group or control group. Treatment participants reported improved attention and performed significantly better on measures of working memory, inhibition, and cognitive flexibility.

The first Class II study evaluated table-top tasks and Rehacom or Attenzione e Concentrazione ${ }^{[19]}$ respectively, depending on age, in 65 children with severe TBI and persistent attention deficits. Comparison of pre/post neuropsychological testing demonstrated improvements in verbal, visual, and overall IQ, sustained attention, and adaptive skills. Compared to a non-treatment group, the intervention group demonstrated a significantly greater recovery in sustained attention and adaptive skills.

The second Class II study evaluated two forms of errorless learning compared to trialand-error learning in 15 children with TBI and 15 matched controls ${ }^{[20]}$. After a 20minute delay, those with TBI performed best under errorless learning conditions; no differences were found in the control group.

The remaining 5 Class III studies evaluated a variety of interventions in various patient populations and reported improved neuropsychological performance, parent ratings, and daily life skills following participation in attention training after TBI. Results of 


\section{Neuropsychological Rehabilitation, published 02/01/2020}

several studies have to be interpreted with caution, however, due to inclusion of mild TBI (mTBI).

Recommendations: Based on results of one Class I study and data from Class II and III studies, attention process training (CRP) is a practice standard for children and adolescents following ABI. Based on the results of a related Class I study, processspecific attention and memory training paired with metacognitive strategy training (Amat-c) is a practice standard for children and adolescents with ABI. Based on results of one Class I study, gist reasoning is a practice guideline. Studies highlight the need for more stringent inclusionary criteria, particularly as related to mild TBI.

Comprehensive: Only one study met criteria for the comprehensive subdomain. This Class III study ${ }^{[21]}$ was a mixed methods case study of music therapy for responsiveness and agitation. The participant was a 10-year-old girl with an acute, severe TBI. She received 10 music therapy sessions over 14 days. A qualified music therapist provided therapy. Based upon the girl's behavioral responses, the therapist adapted his tempo, volume, vocal timbre, and guitar accompaniment to increase the girl's responsiveness and decrease her agitation. Qualitative behavioral analysis identified brief but consistent periods in which the girl displayed increased awareness and responsiveness to the musical stimuli. Quantitative rating of the girl's agitation using the Agitated Behavior Scale produced inconclusive results due to poor inter-rater reliability. 


\section{Neuropsychological Rehabilitation, published 02/01/2020}

Recommendations: Only one comprehensive treatment study meet criteria and it was a Class III study. Therefore there is insufficient evidence to make recommendations regarding specific comprehensive treatments for children with $A B I$. Additional studies of comprehensive treatments are needed.

Emotional control and CBT: Seven studies met criteria for the emotional control domain: 3 Class I, 1 Class II, and 3 Class III.

Two class I studies ${ }^{[22,23]}$ examined efficacy of 8 biweekly and 4 supplemental familybased, counselor-assisted problem-solving sessions (CAPS). These studies included the same sample of 132 children who were 1-6 months post moderate-to-severe TBI and their parents. Families were randomized to either CAPS $(n=65)$ or active internetresource comparison (IRC) control $(n=67)^{[14]}$. Treatment participants had one in-home session, followed by all telehealth sessions. Parent-reported behavioral outcomes ${ }^{[22]}$ and parent-reported social competence levels ${ }^{[23]}$ were examined. Older adolescents enrolled in CAPS had greater improvements in externalizing behaviors than those enrolled in IRC ${ }^{[22]}$. Compared to controls, younger, moderately injured adolescents and older, severely injured teens manifested most improvements in social competence ${ }^{[23]}$. Lower pre-treatment executive dysfunction and higher IQ were associated with greater gains in social competence. 


\section{Neuropsychological Rehabilitation, published 02/01/2020}

A third Class I study ${ }^{[24]}$ explored collaborative care (including care management, CBT, and psychopharmacological consultation) for improving post-concussive symptoms in teens with sport-related mild TBI using self- and caregiver-reports of concussion symptoms, depression, anxiety, and functional status. Adolescents assigned to collaborative care, compared to controls in usual care, showed significant reduction in post-concussive and depressive symptoms and functional improvement at 6 months follow-up. While collaborative care showed promise, efficacy of separate components was not explored.

The single Class II study ${ }^{[25]}$ was a controlled-no treatment, non-randomized trial of CBT targeting disruptive post-TBI neurobehavioral and affective symptoms in 40 post-acute participants ( $4-18$ years of age) with mild, moderate, and severe brain injuries ( $78 \%$ male). Despite limitations, only children in treatment had improved adaptive social skills and reduction in intensity of psychological symptoms.

Two Class III studies were multiple baseline, subject-own-control implementations of individualized, multi-component cognitive behavioral interventions ${ }^{[26,27]}$ for improving behavioral self-regulation. Cases were boys with severe TBI (ages 6 and 17). Educators and family were trained to implement executive functioning supports. Behavioral improvements were observed in each case, suggesting that teaching everyday people in the child's life to assist and support self-regulation may help children with TBI reduce disruptive behaviors. 


\section{Neuropsychological Rehabilitation, published 02/01/2020}

A final Class III study ${ }^{[28]}$ using a pre-post, non-randomized, uncontrolled design, implemented 4-module CBT to improve post-concussive symptoms in adolescents with TBI. Following treatment, children showed reductions in post-concussive symptoms and improvements in quality of life.

Recommendations: Based on the results of two Class I studies on CAPS intervention, family-based problem-solving therapy is a practice standard for older adolescents following TBI. Based on the results of the one Class I study on collaborative care, and supporting Class II, and Class III study findings, CBT may be effective and should be a practice guideline for adolescents following TBI. Class III study findings suggest that helping teachers, classroom aides and caregivers develop individualized behavioral interventions is a practice option for school age children. Studies reviewed highlight the need for larger trials to test efficacy of interventions for improving a wide range of postTBI problems children experience. Future investigators should enroll and randomize children with smaller age ranges, use active control groups, and ensure enough power to detect variations by gender, ethnicity, and severity for improving quality of evidence from trials.

\section{Executive Functioning:}

Eleven studies were reviewed within this domain: 4 Class I, 2 Class II, and 5 Class III. Four Class I studies addressed executive functioning (EF) in adolescents with TBI utilizing 


\section{Neuropsychological Rehabilitation, published 02/01/2020}

internet-based programs $(29,30,31,45)$. The first of which by Wade and colleagues in 2010 ${ }^{[29]}$ utilized a teen online problem-solving program (TOPS) with 41 adolescents. TOPS consisted of cognitive-behavioral and skill-building interventions and were compared with an internet-resource control ${ }^{[14]}$. Significant improvements on an executive symptom scale (BRIEF) and self-reports in severe TBI were observed, while those with moderate TBI lacked significant change. Group differences, especially in older children, were greater on the metacognitive skills, including working memory skills, monitoring, and organizational skills.

Two additional Class I studies by Kurowski et. al ${ }^{[30]}$ and Karver et. al ${ }^{[31]}$ blindly randomized 137 and 132 adolescents, respectively, all with mild to severe TBI into a web-based counselor assisted problem-solving (CAPS) intervention or IRC group. CAPS consisted of counselor-assisted, web-based, family-centered interventions focused on training problem-solving, communication, and self-regulation. Parental-based outcome measures were compared. Kurowski found significant improvements on the BRIEF for high schoolers in the CAPS group. Karver et. al ${ }^{(31)}$ is an adjunct study, randomly assigned to CAPS or IRC and administered a vocabulary measure from an intelligence test. Comparing post-treatment scores, verbal intelligence was associated with greater executive function improvements in the CAPS treatment group.

Two Class II studies described executive interventions using clinical trials. Treble-Barna et al. ${ }^{[32]}$ treated children for 10 -weeks using a combination of computer-assisted 


\section{Neuropsychological Rehabilitation, published 02/01/2020}

attention training tasks and metacognitive strategies. Goal attainment scaling was used to select real life tasks to which the learned strategies would be applied. Compared with non-treated healthy controls, the treatment group demonstrated significant improvements in sustained attention and on the BRIEF. Chan and Fong ${ }^{[33]}$ trained children on problem-solving skills using metacognitive strategies. Children received explicit problem-solving training twice weekly for 7 weeks. Compared with a waiting list control group, those who received problem-solving training demonstrated significant improvements on measures of the components of metacognition, defining the problem, generating alternatives, implementing strategies, and evaluating outcomes. The treatment group also showed improvement on the BRIEF and every-day life performance using the Canadian Occupational Performance Measure (COPM).

Five Class III executive functioning studies were reviewed. One explored the idea of training "everyday people" to act as "cognitive coaches" for children in their application of goal management training in everyday activities ${ }^{[34]}$. A second study focused on computer-based exercises designed to improve cognitive flexibility, attention, and working memory and demonstrated a correlation with frontal lobe fMRI activation ${ }^{[35}$ 2011]. A third supported the ease of use and acceptability of a web-based videoconference training program of a problem-solving intervention to family identified goals ${ }^{[36]}$. Two pilot studies were also reviewed; a combined cognitive behavioral and psycho-educational treatment approach ${ }^{[37]}$ and a preliminary model for improving selfawareness among children in a group based pilot study ${ }^{[38]}$. 


\section{Neuropsychological Rehabilitation, published 02/01/2020}

Recommendations: Three Class I studies, demonstrating the efficacy of online interventions in improving executive functioning strategies for problem-solving, communication, and self-regulation, especially in older children provided strong support for this intervention as a Practice Standard. A Practice Guideline was supported by two strong class II studies that showed effectiveness of the training of metacognitive strategies to improve executive function in children. A second Practice Guideline was identified for using guided internet-based interventions in younger children evidenced by Class I studies and supported by Class III studies. Several Class I and Class III studies support a Practice option for the feasibility of home-based cognitive rehabilitation training on training on Goal Management Training (GMT) with monitoring and interventions through video conferencing. Most studies used parental measures and self-reports as outcome measures. Future research should focus on optimal timeframe for intervention and include performance-based outcomes demonstrating the effects of executive functioning training in everyday life activities, including school and home functioning.

Family/Caregiver: Twelve studies met criteria for the family, caregiver, and teacher intervention subdomain: 11 Class I and 1 Class II.

The first Class I study ${ }^{[39]}$ examined the efficacy of a family intervention, Stepping Stones Triple P (SSTP) combined with Acceptance and Commitment Therapy (ACT), on parent- 


\section{Neuropsychological Rehabilitation, published 02/01/2020}

family adjustment. 59 parents of children with TBI were assessed. Participants were randomly assigned to a care-as-usual control group $(n=29)$ or the SSTP treatment group $(n=30)$. SSTP was delivered over 11 sessions. Results of outcome questionnaires demonstrated improvements in parenting confidence, family functioning, psychological distress, and couple disagreements for the SSTP group.

One Class I study involved the use of a family-centered problem-solving intervention (FPS) to evaluate family outcomes following TBI ${ }^{[40]}$. Families of 32 children with moderate/severe TBI were randomly assigned to the FPS treatment $(n=16)$ or the usual care control group ( $n=16)$. Treatment families reported better parent-child relationships and improvement in child behavior after receiving 7-11 sessions focused on problemsolving and skills training. Another Class I study ${ }^{[41]}$ used an online FPS intervention to evaluate child adjustment. Families of 39 children with moderate to severe TBI were randomly assigned to the FPS group $(n=20)$, which received 14 online sessions, or an IRC ${ }^{[14]}$ control group ( $\left.n=19\right)$. Results of parent-report measures for FPS indicated improvement in child self-management and compliance.

Seven Class I studies involved the use of an online Counselor-Assisted Problem-Solving (CAPS) intervention to evaluate family outcomes following TBI in adolescents ${ }^{\text {[31, 40-45] }}$. These studies sampled 132 families of adolescents 1 to 7 -months post-hospitalization for ABI. Families were randomly assigned to CAPS ( $n=65)$ or an IRC control group $(n=67)$. Treatment participants had one in-home session, followed by 7-11 videoconferencing 


\section{Neuropsychological Rehabilitation, published 02/01/2020}

sessions. Results demonstrated improvement in parent-reported conflicts with adolescents and increased adolescent problem-solving, improvement in adolescent externalizing and internalizing behaviors ${ }^{[22]}$, and improvement in adolescent functional outcomes within the treatment group ${ }^{[45]}$. Results also indicated reduced rates of caregiver psychological distress ${ }^{[42]}$ and decreased parent depression ${ }^{[44]}$. Another Class I study evaluated the effect of parental marital status on participation in the CAPS intervention. Results demonstrated that marital status moderated treatment effects on adolescent externalizing behaviors ${ }^{[43]}$.

A final Class I study ${ }^{[47]}$ involved the use of a Teen Online Problem-Solving-Teens Only (TOPS-TO) intervention to evaluate feasibility and benefits as compared to a TOPSFamily (TOPS-F) intervention. 152 adolescents with moderate to severe TBI were randomly assigned to TOPS-TO, TOPS-F, or an IRC control group. Treatment participants received 10 core and 8 supplemental online sessions. Results indicated feasibility of the TOPS-TO intervention; however, adolescents in the TOPS-F group endorsed closer parent-adolescent relationships.

The only Class II study ${ }^{[48]}$ used a pre/post single group design to evaluate an individualized consultation program, BrainSTARS, for parents and school personnel. 30 children with TBI participated in the study, and parents and school personnel received 3 consultation meetings. Results of the study indicated that the BrainSTARS program may increase parent and teacher proficiencies in addressing the needs of children with $A B I$. 


\section{Neuropsychological Rehabilitation, published 02/01/2020}

Recommendations: Based on the results of the Class I studies on CAPS and familycentered interventions; family-based problem-solving therapy is a practice standard for families of children and adolescents following ABI. Based on the results of the TOPS-TO study, teen-only problem-solving interventions are a practice guideline. Based on the results of the one Class II study, individualized consultation programs for parents and teachers should be a practice guideline for children and adolescents with $\mathrm{ABI}$.

Motor: Two studies, both Class III, met criteria in this domain. The first is that of Missiuna et al. ${ }^{[49]}$. This study investigated the Cognitive Orientation to daily Occupational Performance (CO-OP) approach of metacognitive strategy training among children with TBI and found that these children showed a significant improvement in ability to complete functional activity-based tasks ${ }^{[49]}$. The second Class III study is that of Zlotnik and colleagues ${ }^{[50]}$. This study investigates the Dynamic Interactional Model and Expanded Awareness Model of Toglia ${ }^{[51,52]}$ and found that the model assisted in improving self-care and mobility as well as assisted in identifying awareness of possible deficits in these areas for this two case series ${ }^{[50]}$.

Recommendations: Based on two Class III studies, with limited participants, there is insufficient evidence to make recommendations regarding specific motor/functional activity based treatments for children with acquired brain injury. Additional studies are needed in this area. 


\section{Neuropsychological Rehabilitation, published 02/01/2020}

Technology: 11 technology-based studies met inclusion criteria: 6 Class 1 and 5 Class III. All Technology studies had relatively small sample sizes ranging from 1 to 40 participants.

Researchers presented Class I evidence of Cogmed ${ }^{\mathrm{TM}}$ adaptive training for working memory ${ }^{[53]}$ in 13 children with moderate to severe TBI by investigating the contribution to improvements in WM, attention, reading, and mathematics ${ }^{[54]}$. Children in the training condition (15 session/activity) were compared to a placebo condition. Findings showed that children who received Cogmed ${ }^{\mathrm{TM}}$ made improvements in aspects of WM and reading, but not attention and mathematics.

Several studies examined online home-based interventions for Family Problem-solving (FPS) and Teen Problem-solving (TOPS) ${ }^{[41,55,56]}$. In a pilot Class I study, the FPS intervention was employed to improve parents' mental health following child's TBI ${ }^{[40]}$. Parents were randomized to the FPS $(n=20)$ or IRC ${ }^{[14]}$ group $(n=20)$ for 14 sessions. Findings showed reduced distress, depression, and anxiety in parents. A second Class I study expanded the FPS intervention by including training in executive functioning and language pragmatic skills in the TOPS program ${ }^{[55]}$. Five families received the TOPS intervention with accompanying audio while four received a no-audio condition for 16 sessions. At follow-up, group improvement was observed for the audio condition in internalizing problems, parent depressive symptoms, and parent-adolescent conflict. A subsequent Class I study compared adolescents aged 11-18 years with moderate to 


\section{Neuropsychological Rehabilitation, published 02/01/2020}

severe TBI who underwent $16-20$ sessions of TOPS with an IRC control group ${ }^{[57]}$. TOPS contributed to improvements in parent-teen conflict resolution. A follow-up paper described findings from the parents' perspective to be improvements in problem-solving skills and depressive symptoms, particularly in families from lower income households [56].

Examination of the NeuroPage system for compensation of memory and planning difficulties, worn by the child for 5-7 weeks, was examined in 12 children with neurological deficit ${ }^{[58]}$. In this Class I cross-over trial, all participants made improvements in conducting everyday tasks at follow-up.

Recommendations: Based on results from online self-guided interventions targeting adolescent behavior, parent support, and online practice of cognitive skills, technology interventions can offer a practice guideline for children and adolescents following TBI. A class III study found that helping teachers, classroom aides, and caregivers develop context-sensitive, individualized interventions in the home and classroom setting is a practice option for school aged children to improve independence in self-monitoring and social participation. Studies reviewed highlight the need for more trials with larger samples across age ranges to test efficacy of interventions for improving a wide range of post-TBI cognitive and behavioral problems. 


\section{Neuropsychological Rehabilitation, published 02/01/2020}

The review of technology products for cognitive rehabilitation shows that skills can be improved, but complete understanding of transfer of these improved skills to functioning in everyday life and academic performance is limited. Availability of features in smartphones and children's pre-injury experience with technology provide a means to compensate for acquired cognitive and emotional impairments that has potential to increase self-management and independence.

\section{DISCUSSION}

Summary of evidence: The present study yields the largest EBR of cognitive and behavioral interventions for children with $A B I$ to date, outlining evidence for 8 practice standards, 11 practice guidelines, and 3 practice options (see Table III). Clinicians can use these findings to guide provision of services to children with $A B I$, and researchers may use these findings to target future studies to bolster the strength of evidence in this paper. This EBR presents 28 Class I studies and subsequent Practice Standards, as well as an advanced, systematic literature search conducted by a medical librarian. The previous EBR ${ }^{[1]}$ searched 2 databases using a total of 11 search terms. By comparison, the present EBR searched 5 databases using a total of 37 search terms/concepts. Another strength of this study was the use of a web-based systematic review tool (DistillerSR), ensuring objectivity through blinded, independent reviews. 


\section{Neuropsychological Rehabilitation, published 02/01/2020}

The strongest evidence pertained to family/caregiver-focused interventions including SSTP, FPA, and CAPS. The previous EBR ${ }^{[1]}$ presented evidence of family/caregiverfocused intervention which provided a single practice guideline. The dramatic increase in high quality research on family/caregiver interventions over the past decade resulted in four practice standards and two practice guidelines. These very strong findings implicate family/caregiver training and/or involvement as a "core component" to successful cognitive/behavioral rehabilitation in children with TBI. Indeed, evidence from other domains reviewed throughout this EBR supports the notion that family/caregiver involvement and teaching "everyday people" in the child's life in assisting self-regulation can improve outcome ${ }^{[22,23,26,27]}$.

There was also strong evidence for attention and memory interventions, yielding two practice standards, specifically for attention process training (APT) and Amat-c, as well as one practice guideline for gist reasoning (e.g., SMART). These findings clearly reflect strong efficacy for attention and memory interventions in general, as well as the specific programs employed in the studies. Compared to the previous EBR ${ }^{[1]}$, the present EBR represents extensions of studies included in the 2007 EBR ${ }^{[59]}$ [16] $^{\text {, reflecting continued }}$ advancement of attention rehabilitation in pediatric populations over the past decade.

For the domain of EF interventions, there were practice standards for TOPS and CAPS, practice guidelines for training of metacognitive strategies and guided internet-based interventions in younger children, and a practice option for the feasibility of home- 


\section{Neuropsychological Rehabilitation, published 02/01/2020}

based cognitive rehabilitation training with clinician monitoring via videoconferencing. This represents a new area of study since the prior EBR, in which there were no specific EF interventions.

Regarding emotional/CBT interventions, this EBR found evidence for three recommendations: family-based problem-solving therapy (CAPS) as a practice standard for older adolescents following TBI; a practice guideline for CBT for adolescents; a practice option for interventions that assist "everyday people" (e.g., teachers, caregivers) to develop context-sensitive, individualized interventions in the classroom setting for school-age children with TBI. This reflects improved quality of studies compared to those included in the previous EBR, at which time all of the emotional/CBT studies were of single-subject design methodology ${ }^{[1]}$.

There is strong evidence to support technology-based interventions, including five practice guidelines and one practice option for self-guided, web-based intervention programs, including TOPS, FPS, Neuropage, and CogMed ${ }^{\mathrm{TM}}$. These programs target several domains covered in previous sections (e.g., EF, family problem-solving, social), but are unique in that they are completely self-guided by the patient via internet/computer/tablet. An obvious advantage of this modality is the increased accessibility for patients who live remotely or for families who, due to practical constraints (e.g., work schedule, transportation), are unable to attend frequent therapy appointments. This also reflects trends of the modern era, as many children are 


\section{Neuropsychological Rehabilitation, published 02/01/2020}

considered "technology natives," meaning they have been raised in the digital age. Current cell phone technology offers features such as calendars, alarms, enhanced digital displays, and word processing platforms that teens can use for training and management to improve cognitive and behavioral skills. Potential disadvantages of these interventions are related to the fact that they are completely self-guided. Youths with executive deficits are likely to struggle more with self-guided tasks that require initiation and self-monitoring. Thus, absence of a rehabilitation therapist overseeing the patient's progress may leave the child open to errors that are inherent to his/her brain injury (e.g., anosognosia). Furthermore, review of technology products for cognitive rehabilitation shows that skills can be improved but understanding of transfer/generalizability of these improvements to daily functioning and academic performance is limited.

Beyond the studies included in this EBR, evidence for the efficacy of CogMed in children with $A D H D$ has been inconsistent ${ }^{[60,61]}$, and has been critiqued as lacking generalizability ${ }^{[62,63]}$. The methodology of the single Class I study in this EBR used objective cognitive/neuropsychological and academic achievement measures as outcome variables but did not assess for improvements in everyday functioning. Further research is needed to better understand the impact of technology-based interventions on functional skills. 


\section{Neuropsychological Rehabilitation, published 02/01/2020}

There was only one comprehensive program study included in this EBR, which is in contrast to the eight comprehensive studies in the previous EBR ${ }^{[1]}$. This may reflect the recent trend of studies to target specific domains, such as family/caregiver and technology-based research, which accounts for many studies in the current EBR. Alternatively, it should be mentioned that there are strong comprehensive programs that were not covered in this EBR simply due to the narrow inclusion criteria [64] [65]. Future research may focus on comprehensive programs with well-defined clinical populations.

\section{Study Limitations}

Limitations of this EBR pertained to the stringent inclusion criteria, which excluded many strong studies in the pediatric literature. The inclusion criteria were intentionally narrow in order to limit heterogeneity of participant population and to limit the vast number of studies across all pediatric clinical populations. Despite these efforts, heterogeneity could not be avoided. Two Class I attention \& memory studies ${ }^{[17,18]}$ were limited by heterogeneity of clinical populations, since a significant portion of participants in these studies had mTBI (i.e., concussion). Previous research has consistently shown that $\mathrm{mTBI}$ does not result in long-term cognitive impairments ${ }^{[66,67]}$ [68] [69, 70]; most adolescents recover in less than 3 months ${ }^{[71,72]}[73]$, and post-concussion cognitive complaints are often impacted by non-injury related factors ${ }^{[74-76]}$. Thus, "cognitive impairment" among participants with mTBI in these studies reported over six 


\section{Neuropsychological Rehabilitation, published 02/01/2020}

months post-injury was likely unrelated to injury. Accordingly, generalization to moderate/severe TBI must be considered with caution.

Few studies provided adequate data to guide comment on the influence of age and development on responsiveness to cognitive/behavior rehabilitation interventions. In general, metacognitive and/or self-guided strategies tend to be most efficacious in older adolescents ${ }^{[29,44]}$, whereas younger, school-aged children may benefit more from parent/teacher-guided interventions and increased environmental management in his/her everyday environment ${ }^{[26,27]}$. There is evidence that family problem-solving interventions are effective in school-aged children ${ }^{[40]}$ and adolescents (age 11-18) ${ }^{[57]}$. While these trends in age/developmental-effect may seem intuitive, further research is needed to systematically assess variations in intervention and/or modality on treatment efficacy in children of different developmental levels.

\section{Conclusions}

The present EBR presents numerous practice standards and practice guidelines for family/caregiver involvement and interventions, as well as for direct interventions improving attention, memory, EF, and emotional/behavioral functioning. Integration of technology into treatment delivery shows promise, though further research is needed to ensure generalizability across environments. Differences in treatment provisions may be necessary for different age-ranges, though further research is needed in this area as well. 


\section{Neuropsychological Rehabilitation, published 02/01/2020}

Funding Acknowledgement: The project was partially supported by a grant from the American Congress of Rehabilitation Medicine (ACRM) Brain Injury Special Interest Group (BI-ISAG)

Acknowledgements: We would like to express our gratitude to Dr. Julie HaarbauerKrupa for her contributions and expert guidance on this project.

This research was supported in part by the Intramural Research Program of the National Institutes of Health Clinical Center. The content of this article is solely the responsibility of the authors and does not necessarily represent the official views of the National Institutes of Health, the Department of Health and Human Services, or the United States government.

Disclosure of Interest: Authors report no conflict of interest 


\section{Neuropsychological Rehabilitation, published 02/01/2020}

\section{References}

1. Laatsch, L., et al., An evidence-based review of cognitive and behavioral rehabilitation treatment studies in children with acquired brain injury. $\mathrm{J}$ Head Trauma Rehabil, 2007. 22(4): p. 248-56.

2. $\quad$ Fuentes, M.M., et al., Unmet Rehabilitation Needs After Hospitalization for Traumatic Brain Injury. Pediatrics, 2018. 141(5).

3. Limond, J. and R. Leeke, Practitioner review: cognitive rehabilitation for children with acquired brain injury. J Child Psychol Psychiatry, 2005. 46(4): p. 339-52.

4. Resch, C., et al., Searching for effective components of cognitive rehabilitation for children and adolescents with acquired brain injury: A systematic review. Brain Inj, 2018. 32(6): p. 679-692.

5. $\quad$ Robinson, K.E., et al., Systematic review and meta-analysis of cognitive interventions for children with central nervous system disorders and neurodevelopmental disorders. J Pediatr Psychol, 2014. 39(8): p. 846-65.

6. Slomine, B. and G. Locascio, Cognitive rehabilitation for children with acquired brain injury. Dev Disabil Res Rev, 2009. 15(2): p. 133-43.

7. Linden, M.A., A.E. Glang, and A. McKinlay, A systematic review and metaanalysis of educational interventions for children and adolescents with acquired brain injury. NeuroRehabilitation, 2018. 42(3): p. 311-323.

8. Moher, D., et al., Preferred reporting items for systematic reviews and metaanalyses: the PRISMA statement. PLoS Med, 2009. 6(7): p. e1000097.

9. Moher, D., et al., Preferred reporting items for systematic reviews and metaanalyses: the PRISMA statement. J Clin Epidemiol, 2009. 62(10): p. 1006-12.

10. DistillerSR. 2018; Available from: https://www.evidencepartners.com/products/distillersr-systematic-reviewsoftware/.

11. Cicerone, K.D., et al., Evidence-based cognitive rehabilitation: updated review of the literature from 2003 through 2008. Arch Phys Med Rehabil, 2011. 92(4): p. 519-30.

12. Institute, J.B. Critical Appraisal Tools, The Joanna Briggs Institute (JBI). 2018; Available from: http://joannabriggs.org/research/critical-appraisal-tools.html

13. Edmund, W., Gronseth, G., So, Y., \& Franklin, G., AAN Clinical Practice Guideline Process Manual, in American Academy of Neurology. 2004: St. Paul, Minn.

14. Butler, R.W., et al., A multicenter, randomized clinical trial of a cognitive remediation program for childhood survivors of a pediatric malignancy. $\mathrm{J}$ Consult Clin Psychol, 2008. 76(3): p. 367-78.

15. van 't Hooft, I., et al., Sustained favorable effects of cognitive training in children with acquired brain injuries. NeuroRehabilitation, 2007. 22(2): p. 109-16.

16. Hooft, I.V., et al., Beneficial effect from a cognitive training programme on children with acquired brain injuries demonstrated in a controlled study. Brain Inj, 2005. 19(7): p. 511-8. 


\section{Neuropsychological Rehabilitation, published 02/01/2020}

17. Cook, L.G., et al., Cognitive gains from gist reasoning training in adolescents with chronic-stage traumatic brain injury. Front Neurol, 2014. 5: p. 87.

18. Seguin, M., et al., Ready! Set? Let's Train!: Feasibility of an intensive attention training program and its beneficial effect after childhood traumatic brain injury. Ann Phys Rehabil Med, 2018. 61(4): p. 189-196.

19. Galbiati, S., et al., Attention remediation following traumatic brain injury in childhood and adolescence. Neuropsychology, 2009. 23(1): p. 40-9.

20. Haslam, C., C. Bazen-Peters, and I. Wright, Errorless learning improves memory performance in children with acquired brain injury: a controlled comparison of standard and self-generation techniques. Neuropsychol Rehabil, 2012. 22(5): p. 697-715.

21. Bower, J., et al., Music therapy for early cognitive rehabilitation post-childhood TBI: an intrinsic mixed methods case study. Dev Neurorehabil, 2014. 17(5): p. 339-46.

22. Wade, S.L., et al., Counselor-assisted problem solving (CAPS) improves behavioral outcomes in older adolescents with complicated mild to severe TBI. J Head Trauma Rehabil, 2014. 29(3): p. 198-207.

23. Tlustos, S.J., et al., A randomized problem-solving trial for adolescent brain injury: Changes in social competence. Rehabil Psychol, 2016. 61(4): p. 347-357.

24. McCarty, C.A., et al., Collaborative Care for Adolescents With Persistent Postconcussive Symptoms: A Randomized Trial. Pediatrics, 2016. 138(4).

25. Pastore, V., et al., Efficacy of cognitive behavioural therapy for children and adolescents with traumatic brain injury. Disabil Rehabil, 2011. 33(8): p. 675-83.

26. Feeney, T. and M. Ylvisaker, Context-sensitive cognitive-behavioural supports for young children with TBI: a replication study. Brain Inj, 2006. 20(6): p. 62945.

27. Feeney, T.J., Structured flexibility: the use of context-sensitive self-regulatory scripts to support young persons with acquired brain injury and behavioral difficulties. J Head Trauma Rehabil, 2010. 25(6): p. 416-25.

28. McNally, K.A., et al., Brief cognitive behavioral intervention for children and adolescents with persistent post-concussive symptoms: A pilot study. Child Neuropsychol, 2018. 24(3): p. 396-412.

29. Wade, S.L., et al., A randomized trial of teen online problem solving for improving executive function deficits following pediatric traumatic brain injury. $\mathrm{J}$ Head Trauma Rehabil, 2010. 25(6): p. 409-15.

30. Kurowski, B.G., et al., Online problem-solving therapy for executive dysfunction after child traumatic brain injury. Pediatrics, 2013. 132(1): p. e158-66.

31. Karver, C.L., et al., Cognitive reserve as a moderator of responsiveness to an online problem-solving intervention for adolescents with complicated mild-tosevere traumatic brain injury. Child Neuropsychol, 2014. 20(3): p. 343-57.

32. Treble-Barna, A., et al., Cognitive Intervention for Attention and Executive Function Impairments in Children With Traumatic Brain Injury: A Pilot Study. J Head Trauma Rehabil, 2016. 31(6): p. 407-418.

33. Chan, D.Y. and K.N. Fong, The effects of problem-solving skills training based on metacognitive principles for children with acquired brain injury attending 


\section{Neuropsychological Rehabilitation, published 02/01/2020}

mainstream schools: a controlled clinical trial. Disabil Rehabil, 2011. 33(21-22): p. 2023-32.

34. Krasny-Pacini, A., et al., Context-sensitive goal management training for everyday executive dysfunction in children after severe traumatic brain injury. $\mathrm{J}$ Head Trauma Rehabil, 2014. 29(5): p. E49-64.

35. Kesler, S.R., N.J. Lacayo, and B. Jo, A pilot study of an online cognitive rehabilitation program for executive function skills in children with cancerrelated brain injury. Brain Inj, 2011. 25(1): p. 101-12.

36. Wade, S.L., et al., Brief report: Description of feasibility and satisfaction findings from an innovative online family problem-solving intervention for adolescents following traumatic brain injury. J Pediatr Psychol, 2009. 34(5): p. 517-22.

37. Catroppa, C., V. Anderson, and F. Muscara, Rehabilitation of executive skills post-childhood traumatic brain injury (TBI): A pilot intervention study. Dev Neurorehabil, 2009. 12(5): p. 361-9.

38. Krasny-Pacini, A., et al., Self-awareness assessment during cognitive rehabilitation in children with acquired brain injury: a feasibility study and proposed model of child anosognosia. Disabil Rehabil, 2015. 37(22): p. 2092106.

39. Brown, F.L., et al., Does Stepping Stones Triple P plus Acceptance and Commitment Therapy improve parent, couple, and family adjustment following paediatric acquired brain injury? A randomised controlled trial. Behav Res Ther, 2015. 73: p. 58-66.

40. Wade, S.L., L. Michaud, and T.M. Brown, Putting the pieces together: preliminary efficacy of a family problem-solving intervention for children with traumatic brain injury. J Head Trauma Rehabil, 2006. 21(1): p. 57-67.

41. Wade, S.L., J. Carey, and C.R. Wolfe, An online family intervention to reduce parental distress following pediatric brain injury. J Consult Clin Psychol, 2006. 74(3): p. 445-54.

42. Petranovich, C.L., et al., Long-Term Caregiver Mental Health Outcomes Following a Predominately Online Intervention for Adolescents With Complicated Mild to Severe Traumatic Brain Injury. J Pediatr Psychol, 2015. 40(7): p. 680-8.

43. Raj, S.P., et al., Online Family Problem Solving for Pediatric Traumatic Brain Injury: Influences of Parental Marital Status and Participation on Adolescent Outcomes. J Head Trauma Rehabil, 2018. 33(3): p. 158-166.

44. Wade, S.L., et al., Counselor-assisted problem solving improves caregiver efficacy following adolescent brain injury. Rehabil Psychol, 2014. 59(1): p. 1-9.

45. Wade, S.L., et al., Teen online problem solving for teens with traumatic brain injury: Rationale, methods, and preliminary feasibility of a teen only intervention. Rehabil Psychol, 2017. 62(3): p. 290-299.

46. Narad, M.E., et al., Effects of a Web-Based Intervention on Family Functioning Following Pediatric Traumatic Brain Injury. J Dev Behav Pediatr, 2015. 36(9): p. 700-7.

47. Narad, M.E., et al., Social Participation and Navigation (SPAN): Description and usability of app-based coaching intervention for adolescents with TBI. Dev Neurorehabil, 2018. 21(7): p. 439-448. 


\section{Neuropsychological Rehabilitation, published 02/01/2020}

48. Dise-Lewis, J.E., H.C. Lewis, and C.S. Reichardt, BrainSTARS: pilot data on a team-based intervention program for students who have acquired brain injury. $\mathrm{J}$ Head Trauma Rehabil, 2009. 24(3): p. 166-77.

49. Missiuna, C., et al., Exploring the use of cognitive intervention for children with acquired brain injury. Phys Occup Ther Pediatr, 2010. 30(3): p. 205-19.

50. Zlotnik, S., et al., Use of the Dynamic Interactional Model in self-care and motor intervention after traumatic brain injury: explanatory case studies. Am J Occup Ther, 2009. 63(5): p. 549-58.

51. Toglia, J.P., A dynamic interactional approach to cognitive rehabilitation. Cognition and occupation in rehabilitation: Cognitive models for intervention in occupational therapy 1998: p. 5 - 50.

52. Toglia, J.P., A dynamic interactional approach to cognitive rehabilitation. In $N$. Katz (Ed.). Cognition and occupation in rehabilitation: Cognitive models for intervention in occupational therapy, 2005. 2nd ed.: p. 29 - 72.

53. Beauchamp, M.H., et al., Empirical Derivation and Validation of a Clinical Case Definition for Neuropsychological Impairment in Children and Adolescents. J Int Neuropsychol Soc, 2015. 21(8): p. 596-609.

54. $\quad$ Phillips, N.L., et al., Computerized Working Memory Training for Children with Moderate to Severe Traumatic Brain Injury: A Double-Blind, Randomized, Placebo-Controlled Trial. J Neurotrauma, 2016. 33(23): p. 2097-2104.

55. Wade, S.L., et al., Preliminary efficacy of a Web-based family problem-solving treatment program for adolescents with traumatic brain injury. J Head Trauma Rehabil, 2008. 23(6): p. 369-77.

56. Wade, S.L., et al., A randomized trial of teen online problem solving: efficacy in improving caregiver outcomes after brain injury. Health Psychol, 2012. 31(6): p. 767-76.

57. Wade, S.L., et al., Effect on behavior problems of teen online problem-solving for adolescent traumatic brain injury. Pediatrics, 2011. 128(4): p. e947-53.

58. Wilson, B.A., et al., The NeuroPage system for children and adolescents with neurological deficits. Dev Neurorehabil, 2009. 12(6): p. 421-6.

59. Butler, R.W. and D.R. Copeland, Attentional processes and their remediation in children treated for cancer: a literature review and the development of a therapeutic approach. J Int Neuropsychol Soc, 2002. 8(1): p. 115-24.

60. Cortese, S., et al., Cognitive training for attention-deficit/hyperactivity disorder: meta-analysis of clinical and neuropsychological outcomes from randomized controlled trials. J Am Acad Child Adolesc Psychiatry, 2015. 54(3): p. 164-74.

61. Simone, M., et al., Computer-assisted rehabilitation of attention in pediatric multiple sclerosis and ADHD patients: a pilot trial. BMC Neurol, 2018. 18(1): $\mathrm{p}$ 82.

62. Melby-Lervag, M. and C. Hulme, Is working memory training effective? A metaanalytic review. Dev Psychol, 2013. 49(2): p. 270-91.

63. Melby-Lervag, M., T.S. Redick, and C. Hulme, Working Memory Training Does Not Improve Performance on Measures of Intelligence or Other Measures of "Far Transfer": Evidence From a Meta-Analytic Review. Perspect Psychol Sci, 2016. 11(4): p. 512-34. 


\section{Neuropsychological Rehabilitation, published 02/01/2020}

64. Luton, L.M., et al., A pilot study evaluating an abbreviated version of the cognitive remediation programme for youth with neurocognitive deficits. Brain Inj, 2011. 25(4): p. 409-15.

65. Murdaugh, D.L., T.Z. King, and K. O'Toole, The efficacy of a pilot pediatric cognitive remediation summer program to prepare for transition of care. Child Neuropsychol, 2017: p. 1-21.

66. Belanger, H.G. and R.D. Vanderploeg, The neuropsychological impact of sportsrelated concussion: a meta-analysis. J Int Neuropsychol Soc, 2005. 11(4): p. 34557.

67. Diamond, P.T., et al., Effect of cognitive impairment on rehabilitation outcome. Am J Phys Med Rehabil, 1996. 75(1): p. 40-3.

68. Iverson, G.L., Outcome from mild traumatic brain injury. Curr Opin Psychiatry, 2005. 18(3): p. 301-17.

69. Lovell, M.R., et al., Grade 1 or "ding" concussions in high school athletes. Am J Sports Med, 2004. 32(1): p. 47-54.

70. Solomon, G.S., S.D. Ott, and M.R. Lovell, Long-term neurocognitive dysfunction in sports: what is the evidence? Clin Sports Med, 2011. 30(1): p. 165-77, x-xi.

71. Iverson, G.L., et al., Tracking neuropsychological recovery following concussion in sport. Brain Inj, 2006. 20(3): p. 245-52.

72. McCrea, M., et al., Acute effects and recovery time following concussion in collegiate football players: the NCAA Concussion Study. JAMA, 2003. 290(19): p. 2556-63.

73. Rohling, M.L., et al., A meta-analysis of neuropsychological outcome after mild traumatic brain injury: re-analyses and reconsiderations of Binder et al. (1997), Frencham et al. (2005), and Pertab et al. (2009). Clin Neuropsychol, 2011. 25(4): p. 608-23.

74. Ellis, M.J., et al., Psychiatric outcomes after pediatric sports-related concussion. J Neurosurg Pediatr, 2015. 16(6): p. 709-18.

75. Yeates, K.O., Taylor, H. G., Rusin, J., Bangert, B., Dietrich, A., Nuss, K., \& Wright, M., Premorbid child and family functioning as predictors of postconcussive symptoms in children with mild traumatic brain injuries. Int J Dev Neurosci, 2012. 30(3): p. $231-237$.

76. McNally, K.A., et al., Injury versus noninjury factors as predictors of postconcussive symptoms following mild traumatic brain injury in children. Neuropsychology, 2013. 27(1): p. 1-12.

77. Catroppa, C., et al., Evaluation of an attention and memory intervention postchildhood acquired brain injury: Preliminary efficacy, immediate and 6 months post-intervention. Brain Inj, 2015. 29(11): p. 1317-24.

78. Coyne, J.H., Borg, J. M., DeLuca, J., Glass, L., \& Sumowski, J. F., Retrieval practice as an effective memory strat4egy in children and adolescents with traumatic brain injury. Arch Phys Med Rehabil, 2015. 96(4): p. 742-745.

79. Ho, J., et al., Rehabilitation of everyday memory deficits in paediatric brain injury: self-instruction and diary training. Neuropsychol Rehabil, 2011. 21(2): p. 183-207.

80. Kaldoja, M.L., et al., Neuropsychological benefits of computer-assisted cognitive rehabilitation (using FORAMENRehab program) in children with mild traumatic 


\section{Neuropsychological Rehabilitation, published 02/01/2020}

brain injury or partial epilepsy: A pilot study. J Pediatr Rehabil Med, 2015. 8(4): p. 271-83.

81. Sjo, N.M., et al., Training of attention and memory deficits in children with acquired brain injury. Acta Paediatr, 2010. 99(2): p. 230-6.

82. van't Hooft, I. and A.L. Norberg, SMART cognitive training combined with a parental coaching programme for three children treated for medulloblastoma. NeuroRehabilitation, 2010. 26(2): p. 105-13.

83. Wade, S.L., et al., Online problem-solving therapy after traumatic brain injury: a randomized controlled trial. Pediatrics, 2015. 135(2): p. e487-95.

84. Wade, S.L., et al., Long-Term Behavioral Outcomes after a Randomized, Clinical Trial of Counselor-Assisted Problem Solving for Adolescents with Complicated Mild-to-Severe Traumatic Brain Injury. J Neurotrauma, 2015. 32(13): p. 967-75.

85. Dexheimer, J.W., et al., Usability evaluation of the SMART application for youth with mTBI. Int J Med Inform, 2017. 97: p. 163-170.

86. Janssen, J., et al., Structured game-related group therapy for an adolescent with Acquired Brain Injury: a case report. J Pediatr Rehabil Med, 2012. 5(2): p. 12532.

87. Kurowski, B.G., et al., Feasibility and Potential Benefits of a Web-Based Intervention Delivered Acutely After Mild Traumatic Brain Injury in Adolescents: A Pilot Study. J Head Trauma Rehabil, 2016. 31(6): p. 369-378.

88. Depompei, R., et al., Practical applications for use of PDAs and smartphones with children and adolescents who have traumatic brain injury.

NeuroRehabilitation, 2008. 23(6): p. 487-99. 


\section{Neuropsychological Rehabilitation, published 02/01/2020}

Figure I: FLOW CHART - Provides the number of manuscripts under review at each stage of the search process using PRISMA guidelines ${ }^{(8,9)}$

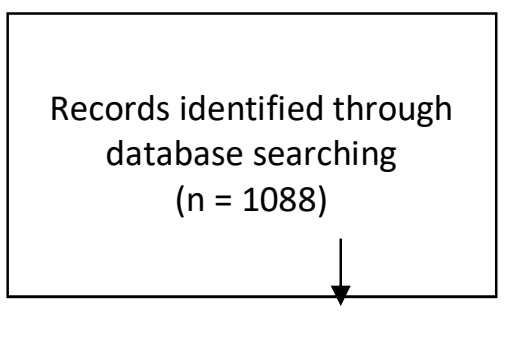
Additional records identified through other sources

$$
(n=2)
$$

Wade et al., (2014) to Emotional \& CBT Narad et al. (2014) to Technology

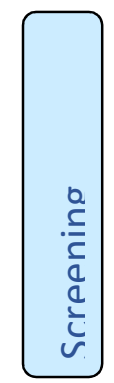

Duplicates removed $(n=36)$
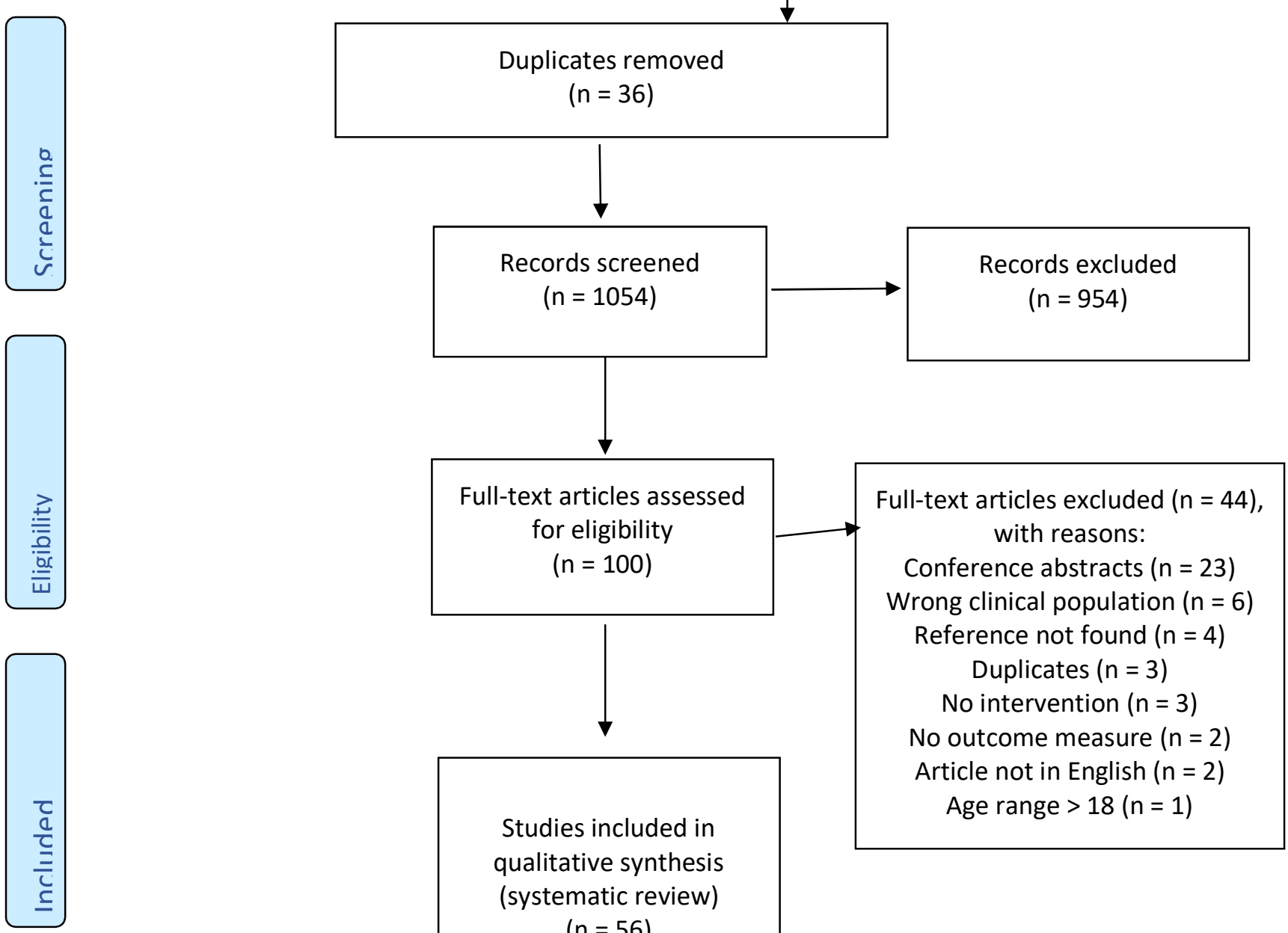

qualitative synthesis (systematic review)

$$
(n=56)
$$


Neuropsychological Rehabilitation, published 02/01/2020

Table I: Search strategy and terms: completed December 2017

\section{DATA BASES:}

Embase 1947-current, Ovid Medline 1946-current, Scopus 1823-current, PsycINFO 1880s-current, and clinicaltrials.gov 1997-current

INITIAL SEARCH TERMS:

Cognitive rehabilitation, speech therapy, language therapy, attention training, cognitive remediation therapy, remediation training, cogmed, brainsteps, neuropsychological rehabilitation, working memory training, vocational rehabilitation, occupational therapy, memory training, memory training problem-solving

AND

Pediatrics, child, adolescent, toddler, infant, teen, youth juvenile, pediatric, pediatry AND

Traumatic brain injury, brain lesion encephalopathy, cerebral lesion, brain system trauma, cerebral trauma, organic cerebral trauma, traumatic brain injury, posttraumatic encephalopathy, acquired brain injury, brain injury(s), cerebral injury(s), cerebrum lesion(s), left hemisphere injury, right hemisphere injury 
Neuropsychological Rehabilitation, published 02/01/2020

Table II: Evidence-based classification of $\mathbf{5 6}$ studies meeting criteria

\begin{tabular}{|c|c|c|c|c|c|}
\hline $\begin{array}{l}\text { Treatment } \\
\text { Domain }\end{array}$ & Authors & Year & $\begin{array}{l}\text { Total } \\
\text { Subjects } \\
\text { Enrolled }\end{array}$ & $\begin{array}{l}/ N \\
\text { Significant } \\
\text { Results }\end{array}$ & $\begin{array}{l}\text { Classification } \\
\text { Given by } \\
\text { Reviewers }\end{array}$ \\
\hline \multirow[t]{12}{*}{$\begin{array}{l}\text { Attention and } \\
\text { Memory }\end{array}$} & $\begin{array}{l}\text { Butler, R.W. } \\
\text { et al. }{ }^{[14]}\end{array}$ & 2008 & 161 & $Y$ & 1 \\
\hline & $\begin{array}{l}\text { Catroppa, C. } \\
\text { et al. }{ }^{[77]}\end{array}$ & 2016 & 10 & $Y$ & III \\
\hline & $\begin{array}{l}\text { Cook, L et al. } \\
{[17]}\end{array}$ & 2017 & 20 & $Y$ & 1 \\
\hline & $\begin{array}{l}\text { Coyne, J et al. } \\
\text { [78] }\end{array}$ & 2015 & 15 & $N$ & III \\
\hline & $\begin{array}{l}\text { Galbiati, S. et } \\
\text { al. }{ }^{[19]}\end{array}$ & 2009 & 65 & $Y$ & II \\
\hline & $\begin{array}{l}\text { Haslam, C et } \\
\text { al. [20] }\end{array}$ & 2012 & 30 & $Y$ & II \\
\hline & $\begin{array}{l}\text { Ho, J. et. al. } \\
\text { [79] }\end{array}$ & 2011 & 15 & $Y$ & III \\
\hline & $\begin{array}{l}\text { Kaldoja, M. } \\
\text { et. al. }{ }^{[80]}\end{array}$ & 2015 & 26 & $Y$ & III \\
\hline & $\begin{array}{l}\text { Sequin, M., } \\
\text { et al. [18] }\end{array}$ & 2018 & 17 & $Y$ & 1 \\
\hline & $\begin{array}{l}\text { Sjo, } \mathrm{N} \text { et al. } \\
{[81]}\end{array}$ & 2010 & 7 & $Y$ & III \\
\hline & $\begin{array}{l}\text { Van't Hoooft, } \\
\text { T., et al. }{ }^{[15]}\end{array}$ & 2007 & 38 & $Y$ & 1 \\
\hline & $\begin{array}{l}\text { Van't Hoooft, } \\
\text { T., et al. }{ }^{[82]}\end{array}$ & 2010 & 3 & $N$ & III \\
\hline
\end{tabular}


Neuropsychological Rehabilitation, published 02/01/2020

\begin{tabular}{|c|c|c|c|c|c|}
\hline Comprehensive & $\begin{array}{l}\text { Bower, } \\
\text { J.,Grocke, D, } \\
\text { Shoemark, H } \\
\text { [21] }\end{array}$ & 2014 & 1 & $\mathrm{~N}$ & III \\
\hline \multirow{7}{*}{$\begin{array}{l}\text { Emotional and } \\
\text { CBT }\end{array}$} & Feeney ${ }^{[27]}$ & 2010 & 2 & $\mathrm{~N}$ & III \\
\hline & Feeney ${ }^{[26]}$ & 2006 & 2 & $\mathrm{~N}$ & III \\
\hline & $\begin{array}{l}\text { McCarty, et } \\
\text { al. [24] }\end{array}$ & 2016 & 29 & $\mathrm{Y}$ & 1 \\
\hline & $\begin{array}{l}\text { Pastore, } \mathrm{V} \text { et } \\
\text { al. }{ }^{[25]}\end{array}$ & 2007 & 40 & $Y$ & II \\
\hline & $\begin{array}{l}\text { Tlustos, S. et } \\
\text { al. [23] }\end{array}$ & 2016 & 132 & $Y$ & 1 \\
\hline & $\begin{array}{l}\text { Wade, S. et } \\
\text { al. }{ }^{[44]}\end{array}$ & 2012 & 132 & $Y$ & 1 \\
\hline & $\begin{array}{l}\text { Kelly, A. et al. } \\
{[28]}\end{array}$ & 2017 & 31 & $\mathrm{Y}$ & III \\
\hline \multirow[t]{6}{*}{$\begin{array}{l}\text { Executive } \\
\text { Functioning }\end{array}$} & $\begin{array}{l}\text { Catroppe, C } \\
\text { and Muscara, } \\
F^{[37]}\end{array}$ & 2009 & 3 & $Y$ & III \\
\hline & Chan, D [33] & 2011 & 32 & $Y$ & II \\
\hline & $\begin{array}{l}\text { Karver, C, et } \\
\text { al. }{ }^{[31]}\end{array}$ & 2014 & 132 & $Y$ & 1 \\
\hline & Kesler, S. ${ }^{[35]}$ & 2011 & 23 & $Y$ & III \\
\hline & $\begin{array}{l}\text { Krasny- } \\
\text { Pacini, A. , et } \\
\text { al. }{ }^{[34]}\end{array}$ & 2014 & 5 & $Y$ & III \\
\hline & $\begin{array}{l}\text { Krasny- } \\
\text { Pacini, A., et } \\
\text { al. }{ }^{[38]}\end{array}$ & 2015 & 5 & $Y$ & III \\
\hline
\end{tabular}


Neuropsychological Rehabilitation, published 02/01/2020

\begin{tabular}{|c|c|c|c|c|c|}
\hline & $\begin{array}{l}\text { Kurowski, B., } \\
\text { et. al. }{ }^{[30]}\end{array}$ & 2013 & 132 & $Y$ & 1 \\
\hline & $\begin{array}{l}\text { Treble-Barna, } \\
\text { A., Harn, B., } \\
\text { Wade, C. }{ }^{[32]}\end{array}$ & 2016 & 24 & $Y$ & II \\
\hline & $\begin{array}{l}\text { Wade, S., et } \\
\text { al. }{ }^{[45]}\end{array}$ & 2017 & 153 & $\mathrm{Y}$ & 1 \\
\hline & $\begin{array}{l}\text { Wade, S., et } \\
\text { al. [29] }\end{array}$ & 2010 & 35 & $Y$ & 1 \\
\hline & $\begin{array}{l}\text { Wade, S., et } \\
\text { al. }{ }^{[36]}\end{array}$ & 2009 & 9 & $Y$ & III \\
\hline Family/ Caregiver & $\begin{array}{l}\text { Brown, F., et } \\
\text { al. [39] }\end{array}$ & 2015 & 59 & $Y$ & 1 \\
\hline & $\begin{array}{l}\text { Dise-Lewis, J., } \\
\text { et al. }{ }^{[48]}\end{array}$ & 2009 & 30 & $Y$ & II \\
\hline & $\begin{array}{l}\text { Narad, M., et } \\
\text { al. }{ }^{[46]}\end{array}$ & 2015 & 132 & $Y$ & 1 \\
\hline & $\begin{array}{l}\text { Patranovich, } \\
\text { C., et al. }{ }^{[42]}\end{array}$ & 2015 & 132 & $Y$ & 1 \\
\hline & $\begin{array}{l}\text { Raj, S., et al. } \\
{[43]}\end{array}$ & 2017 & 129 & $Y$ & 1 \\
\hline & $\begin{array}{l}\text { Wade, S., and } \\
\text { Brown, T. }{ }^{[40]}\end{array}$ & 2006 & 32 & $Y$ & 1 \\
\hline & $\begin{array}{l}\text { Wade, S., } \\
\text { Carey, J., } \\
\text { Wolfe, C. }{ }^{[41]}\end{array}$ & 2006 & 44 & $Y$ & 1 \\
\hline & $\begin{array}{l}\text { Wade, S. and } \\
\text { Taylor, H. }{ }^{[44]}\end{array}$ & 2014 & 132 & $Y$ & 1 \\
\hline & $\begin{array}{l}\text { Wade, S., et } \\
\text { al. }{ }^{[22]}\end{array}$ & 2014 & 132 & $Y$ & 1 \\
\hline
\end{tabular}


Neuropsychological Rehabilitation, published 02/01/2020

\begin{tabular}{|c|c|c|c|c|c|}
\hline & $\begin{array}{l}\text { Wade, S., et } \\
\text { al. }{ }^{[83]}\end{array}$ & 2015 & 132 & $Y$ & 1 \\
\hline & $\begin{array}{l}\text { Wade, S., } \\
\text { Cassidy, A., et } \\
\text { al. }{ }^{[84]}\end{array}$ & 2015 & 132 & $Y$ & 1 \\
\hline & $\begin{array}{l}\text { Wade, S., et } \\
\text { al. }{ }^{[45]}\end{array}$ & 2017 & 101 & $Y$ & 1 \\
\hline \multirow[t]{2}{*}{$\begin{array}{l}\text { Motor/Functional } \\
\text { Skills }\end{array}$} & $\begin{array}{l}\text { Missiuna, C., } \\
\text { et al. }{ }^{[49]}\end{array}$ & 2010 & 6 & $Y$ & III \\
\hline & $\begin{array}{l}\text { Zlotnik, S., et } \\
\text { al. }{ }^{[50]}\end{array}$ & 2009 & 2 & $Y$ & III \\
\hline \multirow[t]{8}{*}{ Technology } & $\begin{array}{l}\text { Dexheimer, } \\
\text { J., et al. }{ }^{[85]}\end{array}$ & 2017 & 8 & $N$ & III \\
\hline & $\begin{array}{l}\text { Janssen, J., et } \\
\text { al. }{ }^{866]}\end{array}$ & 2012 & 1 & $N$ & III \\
\hline & $\begin{array}{l}\text { Kurowski, B., } \\
\text { et al. }{ }^{87]}\end{array}$ & 2016 & 21 & $Y$ & III \\
\hline & $\begin{array}{l}\text { Phillips, N., et } \\
\text { al. [54] }\end{array}$ & 2016 & 27 & $Y$ & 1 \\
\hline & $\begin{array}{l}\text { DePompei, } \\
\text { R., et al. }{ }^{88]}\end{array}$ & 2008 & 106 & & III \\
\hline & $\begin{array}{l}\text { Narad, M., } \\
\text { Bedel, G., } \\
\text { King, J. }{ }^{[47]}\end{array}$ & 2014 & 4 & $Y$ & III \\
\hline & $\begin{array}{l}\text { Wade, S., } \\
\text { Carey, J. } \\
\text { Wolfe, C }\end{array}$ & 2006 & 40 & $Y$ & 1 \\
\hline & $\begin{array}{l}\text { Wade, S., } \\
\text { Carey, J., } \\
\text { Williams, K., } \\
{[55]}\end{array}$ & 2008 & 9 & $Y$ & I \\
\hline
\end{tabular}


Neuropsychological Rehabilitation, published 02/01/2020

\begin{tabular}{|l|l|l|l|l|l|}
\hline & $\begin{array}{l}\text { Wade, S., et } \\
\text { al. }{ }^{[57]}\end{array}$ & 2011 & 41 & Y & I \\
\hline & $\begin{array}{l}\text { Wade, S., et } \\
\text { al. [56] }\end{array}$ & 2012 & 42 & Y & I \\
\hline & $\begin{array}{l}\text { Wilson, B., et } \\
\text { al. [58] }\end{array}$ & 2012 & 12 & Y & I \\
\hline
\end{tabular}

Table III: Treatment domain, name and description of intervention, level of practice recommendation, specific limitation(s) in recommendation based on study elements

\begin{tabular}{|c|c|c|c|}
\hline $\begin{array}{l}\text { TREATMENT } \\
\text { DOMAIN }\end{array}$ & $\begin{array}{l}\text { NAME AND } \\
\text { DESCRIPTION OF } \\
\text { INTERVENTION }\end{array}$ & $\begin{array}{l}\text { LEVEL OF } \\
\text { RECOMMENDATION }\end{array}$ & $\begin{array}{l}\text { SPECIFIC } \\
\text { LIMITATIONS IN } \\
\text { RECOMMENATION }\end{array}$ \\
\hline $\begin{array}{l}\text { Attention \& } \\
\text { memory }\end{array}$ & $\begin{array}{l}\text { Attention Process } \\
\text { Training (APT) }\end{array}$ & Practice Standard & $\begin{array}{l}\text { Possible limited } \\
\text { applicability to } \\
\text { moderate and } \\
\text { severe TBI given } \\
\text { that mTBI } \\
\text { participants } \\
\text { without verified } \\
\text { cognitive deficits } \\
\text { were included }\end{array}$ \\
\hline $\begin{array}{l}\text { Attention \& } \\
\text { memory }\end{array}$ & $\begin{array}{l}\text { Amsterdam } \\
\text { Memory and } \\
\text { Attention Training } \\
\text { for Children } \\
\text { (Amat-c): process- } \\
\text { specific attention } \\
\text { and memory } \\
\text { training with } \\
\text { metacognitive } \\
\text { strategy training }\end{array}$ & Practice Standard & $\begin{array}{l}\text { Small and } \\
\text { heterogeneous } \mathrm{ABI} \\
\text { sample with } \\
\text { significantly more } \\
\text { children with brain } \\
\text { tumors, possible } \\
\text { experimenter } \\
\text { effects due to three } \\
\text { of the authors } \\
\text { providing a portion } \\
\text { of the intervention, } \\
\text { active ingredients } \\
\text { of the treatment } \\
\text { not identified, no } \\
\text { activities and } \\
\text { participation-level } \\
\text { outcome measures. }\end{array}$ \\
\hline $\begin{array}{l}\text { Attention \& } \\
\text { memory }\end{array}$ & Gist Reasoning & Practice Guideline & $\begin{array}{l}\text { Possible limited } \\
\text { applicability to }\end{array}$ \\
\hline
\end{tabular}




\begin{tabular}{|c|c|c|c|}
\hline & & & $\begin{array}{l}\text { moderate and } \\
\text { severe TBI given } \\
\text { that } \mathrm{mTBI} \\
\text { participants } \\
\text { without verified } \\
\text { cognitive deficits } \\
\text { were included }\end{array}$ \\
\hline $\begin{array}{l}\text { Emotional Control } \\
\& \mathrm{CBT}\end{array}$ & $\begin{array}{l}\text { Family-based } \\
\text { problem-solving }\end{array}$ & Practice Standard & $\begin{array}{l}\text { Need more } \\
\text { information about } \\
\text { specific treatment } \\
\text { before treatment } \\
\text { can implemented } \\
\text { by clinicians; } \\
\text { limited power to } \\
\text { detect differences } \\
\text { in subgroups (e.g., } \\
\text { age, gender, SES) }\end{array}$ \\
\hline $\begin{array}{l}\text { Emotional Control } \\
\& \mathrm{CBT}\end{array}$ & CBT & Practice Guideline & $\begin{array}{l}\text { Class I study did not } \\
\text { isolate } \\
\text { effectiveness of } \\
\text { CBT versus other } \\
\text { intervention } \\
\text { components }\end{array}$ \\
\hline $\begin{array}{l}\text { Emotional Control } \\
\& \mathrm{CBT}\end{array}$ & $\begin{array}{l}\text { Strategies to } \\
\text { promote executive } \\
\text { functions in the } \\
\text { classroom }\end{array}$ & Practice Option & $\begin{array}{l}\text { Only four cases } \\
\text { were provided; } \\
\text { highly intensive and } \\
\text { individualized } \\
\text { treatment; age } \\
\text { range is wide }\end{array}$ \\
\hline $\begin{array}{l}\text { Executive } \\
\text { Functioning }\end{array}$ & $\begin{array}{l}\text { Online Based } \\
\text { Problem-solving } \\
\text { Interventions }\end{array}$ & Practice Standard & $\begin{array}{l}\text { Expectation and } \\
\text { selection bias may } \\
\text { limit } \\
\text { generalizability } \\
\text { Measures of EF are } \\
\text { based on } \\
\text { self/family rating } \\
\text { scales but not on } \\
\text { actual measures of } \\
\text { EF performance }\end{array}$ \\
\hline $\begin{array}{l}\text { Executive } \\
\text { Functioning }\end{array}$ & $\begin{array}{l}\text { Metacognitive } \\
\text { Training; defining } \\
\text { the problem, } \\
\text { generating }\end{array}$ & Practice Guideline & $\begin{array}{l}\text { Lack of long-term } \\
\text { follow-up, unable } \\
\text { to determine if } \\
\text { gains are }\end{array}$ \\
\hline
\end{tabular}




\begin{tabular}{|c|c|c|c|}
\hline & $\begin{array}{l}\text { alternatives, } \\
\text { implanting } \\
\text { strategies, } \\
\text { evaluating } \\
\text { outcomes }\end{array}$ & & $\begin{array}{l}\text { maintained over } \\
\text { time, measures } \\
\text { based on parent- } \\
\text { child perception } \\
\text { and not on actual } \\
\text { problem-solving } \\
\text { performance }\end{array}$ \\
\hline $\begin{array}{l}\text { Executive } \\
\text { Functioning }\end{array}$ & $\begin{array}{l}\text { Guided Internet- } \\
\text { Based } \\
\text { Interventions for } \\
\text { younger } \\
\text { population (i.e. } \\
\text { Counselor } \\
\text { Assisted) }\end{array}$ & Practice Guideline & $\begin{array}{l}\text { Lack of long-term } \\
\text { follow-up, unable } \\
\text { to determine if } \\
\text { gains are } \\
\text { maintained over } \\
\text { time, } \\
\text { heterogeneous } \\
\text { samples; unable to } \\
\text { isolate effects of EF } \\
\text { interventions, EF } \\
\text { measures were } \\
\text { based on } \\
\text { self/family rating } \\
\text { scales, should aim } \\
\text { to use teacher } \\
\text { reports and } \\
\text { ecologically valid } \\
\text { performance } \\
\text { measure, small } \\
\text { sample size }\end{array}$ \\
\hline $\begin{array}{l}\text { Executive } \\
\text { Functioning }\end{array}$ & $\begin{array}{l}\text { Home Based } \\
\text { Cognitive } \\
\text { Remediation } \\
\text { Training, Goal } \\
\text { Management } \\
\text { Training and Video } \\
\text { Conferencing/ } \\
\text { Skype }\end{array}$ & Practice Option & $\begin{array}{l}\text { For higher levels of } \\
\text { evidence, future } \\
\text { studies should } \\
\text { address the } \\
\text { following: Expand } \\
\text { the role of parental } \\
\text { coaching, increase } \\
\text { duration of } \\
\text { intervention, } \\
\text { maintain direct } \\
\text { contact with } \\
\text { schools/teachers to } \\
\text { reinforce goals and } \\
\text { monitor progress }\end{array}$ \\
\hline Family/Caregiver & $\begin{array}{l}\text { Family behavioral } \\
\text { intervention, }\end{array}$ & Practice Standard & $\begin{array}{l}\text { Outcome measures } \\
\text { dominated by self- }\end{array}$ \\
\hline
\end{tabular}




\begin{tabular}{|c|c|c|c|}
\hline & $\begin{array}{l}\text { Stepping Stones } \\
\text { Triple P (SSTP) } \\
\text { combined with } \\
\text { ACT with an } \\
\text { overall study aim } \\
\text { to improve parent- } \\
\text { family adjustment }\end{array}$ & & $\begin{array}{l}\text { report; some } \\
\text { effects were not } \\
\text { maintained at the } \\
\text { six month follow- } \\
\text { up; study did not } \\
\text { take place in a } \\
\text { rehabilitation } \\
\text { setting; sample was } \\
\text { largely Caucasian }\end{array}$ \\
\hline Family/Caregiver & $\begin{array}{l}\text { Family-centered } \\
\text { problem-solving } \\
\text { and skill building } \\
\text { intervention (FPS). } \\
\text { The overall aim of } \\
\text { the intervention } \\
\text { was to improve } \\
\text { child behavior } \\
\text { following TBI and } \\
\text { improve family } \\
\text { relationships. }\end{array}$ & Practice Standard & $\begin{array}{l}\text { Small sample size } \\
\text { with heterogeneity } \\
\text { in injury severity; } \\
\text { the control group } \\
\text { received usual care } \\
\text { only; outcome } \\
\text { measures were } \\
\text { dominated by self- } \\
\text { report; the } \\
\text { experience level of } \\
\text { the therapist } \\
\text { providing the } \\
\text { intervention was } \\
\text { not controlled }\end{array}$ \\
\hline Family/Caregiver & $\begin{array}{l}\text { Online FPS } \\
\text { compared to an } \\
\text { internet-resource } \\
\text { control group. The } \\
\text { main aim of the } \\
\text { intervention was } \\
\text { to improve child } \\
\text { adjustment }\end{array}$ & Practice Standard & $\begin{array}{l}\text { Relatively small } \\
\text { sample size with } \\
\text { more mild injuries } \\
\text { over-represented in } \\
\text { the sample; } \\
\text { outcome measures } \\
\text { were dominated by } \\
\text { self-report; long- } \\
\text { term follow-up was } \\
\text { not completed }\end{array}$ \\
\hline $\begin{array}{l}\text { Family/Caregiver } \\
\text { intervention }\end{array}$ & $\begin{array}{l}\text { Problem-solving } \\
\text { intervention, Teen } \\
\text { Online Problem- } \\
\text { solving - Teen } \\
\text { Only (TOPS-TO). } \\
\text { The objective was } \\
\text { to improve teen } \\
\text { satisfaction with a } \\
\text { teen-only problem- } \\
\text { solving } \\
\text { intervention }\end{array}$ & Practice Guideline & $\begin{array}{l}\text { Data regarding } \\
\text { comparison efficacy } \\
\text { between TOPS-TO } \\
\text { and TOPS-F was } \\
\text { not included; } \\
\text { preference in } \\
\text { treatment modality } \\
\text { between parents and } \\
\text { adolescents was not } \\
\text { assessed; relatively } \\
\text { small number of }\end{array}$ \\
\hline
\end{tabular}




\begin{tabular}{|c|c|c|c|}
\hline & $\begin{array}{l}\text { involving parents } \\
\text { following ABI. }\end{array}$ & & $\begin{array}{l}\text { nonwhite } \\
\text { participants were } \\
\text { included in the } \\
\text { study }\end{array}$ \\
\hline Family/Caregiver & $\begin{array}{l}\text { Online Counselor- } \\
\text { Assisted Problem- } \\
\text { solving (CAPS), } \\
\text { with the objective } \\
\text { to improve family } \\
\text { and parent } \\
\text { outcomes } \\
\text { following TBI in } \\
\text { adolescents }\end{array}$ & Practice Standard & $\begin{array}{l}\text { Outcome measures } \\
\text { dominated by self- } \\
\text { report; intervention } \\
\text { focuses on } \\
\text { adolescents with } \\
\text { TBI only; all papers } \\
\text { in this group } \\
\text { emerged from the } \\
\text { same study } \\
\text { cohort/same } \\
\text { investigators; the } \\
\text { control group } \\
\text { received internet- } \\
\text { resource support } \\
\text { only; optimal } \\
\text { dosing not explored }\end{array}$ \\
\hline Family/Caregiver & $\begin{array}{l}\text { Individualized } \\
\text { consultation } \\
\text { program, } \\
\text { BrainSTARS, } \\
\text { designed for } \\
\text { parents and school } \\
\text { personnel to the } \\
\text { needs of children } \\
\text { with ABI in the } \\
\text { school setting }\end{array}$ & Practice Guideline & $\begin{array}{l}\text { Randomization not } \\
\text { included in design; } \\
\text { covered a wide age } \\
\text { range with a } \\
\text { relative small } \\
\text { sample size for each } \\
\text { age category; time- } \\
\text { post injury was not } \\
\text { controlled for } \\
\text { related to the timing } \\
\text { of the intervention }\end{array}$ \\
\hline \begin{tabular}{|l|} 
Technology- \\
Working memory
\end{tabular} & $\begin{array}{l}\text { COGmed }^{\mathrm{TM}} \\
\text { program: working } \\
\text { memory by } \\
\text { manipulation and } \\
\text { storage of verbal } \\
\text { and/or } \\
\text { visuospatial } \\
\text { information } \\
\end{array}$ & Practice Guideline & $\begin{array}{l}\text { Applies to reading } \\
\text { but not other } \\
\text { academic subject } \\
\text { areas. }\end{array}$ \\
\hline $\begin{array}{l}\text { Technology- } \\
\text { Parent Adjustment }\end{array}$ & $\begin{array}{l}\text { Web-based self- } \\
\text { guided Family } \\
\text { Problem-Solving } \\
\text { therapy (FPS) }\end{array}$ & Practice Guideline & $\begin{array}{l}\text { This directly } \\
\text { addresses the } \\
\text { treatment in } \\
\text { question but does } \\
\text { not demonstrate } \\
\text { applicability to }\end{array}$ \\
\hline
\end{tabular}


Neuropsychological Rehabilitation, published 02/01/2020

\begin{tabular}{|c|c|c|c|}
\hline & & & $\begin{array}{l}\text { cognition or } \\
\text { cognitive } \\
\text { rehabilitation }\end{array}$ \\
\hline $\begin{array}{l}\text { Technology- } \\
\text { Adolescent and } \\
\text { Parent } \\
\text { psychosocial } \\
\text { adjustment }\end{array}$ & $\begin{array}{l}\text { Web-based self- } \\
\text { guided Teen } \\
\text { Problem-Solving } \\
\text { therapy (TOPS): } \\
\text { targets executive } \\
\text { function, social } \\
\text { skills and } \\
\text { adolescent self- } \\
\text { monitoring of } \\
\text { behavior with } \\
\text { parental support }\end{array}$ & Practice Guideline & $\begin{array}{l}\text { The intervention } \\
\text { resulted in } \\
\text { improved } \\
\text { adolescent } \\
\text { internalizing } \\
\text { behaviors and } \\
\text { depression; } \\
\text { however, } \\
\text { generalization to } \\
\text { cognition and } \\
\text { cognitive } \\
\text { rehabilitation was } \\
\text { not described. }\end{array}$ \\
\hline $\begin{array}{l}\text { Technology- } \\
\text { Problem-solving } \\
\text { Skills }\end{array}$ & $\begin{array}{l}\text { Web-based self- } \\
\text { guided Teen } \\
\text { problem-solving } \\
\text { intervention } \\
\text { (TOPS): executive } \\
\text { function, social } \\
\text { skills and } \\
\text { adolescent self- } \\
\text { monitoring of } \\
\text { behavior with } \\
\text { parental support }\end{array}$ & Practice Guideline & $\begin{array}{l}\text { The intervention } \\
\text { resulted in } \\
\text { improved } \\
\text { adolescent } \\
\text { problem-solving } \\
\text { and reduction in } \\
\text { parent-teen } \\
\text { conflicts; however, } \\
\text { generalization to } \\
\text { cognition and } \\
\text { cognitive } \\
\text { rehabilitation was } \\
\text { not described. }\end{array}$ \\
\hline $\begin{array}{l}\text { Technology- } \\
\text { Memory and } \\
\text { planning for daily } \\
\text { self-selected tasks }\end{array}$ & $\begin{array}{l}\text { Individualized } \\
\text { reminders for daily } \\
\text { tasks } \\
\text { automatically sent } \\
\text { to a device } \\
\text { (Neuropage) }\end{array}$ & Practice Guideline & $\begin{array}{l}\text { Individualized } \\
\text { reminders } \\
\text { delivered via } \\
\text { technology improve } \\
\text { memory and } \\
\text { planning for } \\
\text { everyday tasks. The } \\
\text { association } \\
\text { between cognitive } \\
\text { skills, cognitive } \\
\text { rehabilitation and } \\
\text { daily tasks requires } \\
\text { further } \\
\text { investigation. }\end{array}$ \\
\hline
\end{tabular}


Neuropsychological Rehabilitation, published 02/01/2020

\begin{tabular}{|c|c|c|c|}
\hline $\begin{array}{l}\text { Technology- } \\
\text { Independence and } \\
\text { Participation }\end{array}$ & $\begin{array}{l}\text { Methods which } \\
\text { used APPS, the } \\
\text { Nintendo WII }{ }^{\circledR} \text { and } \\
\text { personal data } \\
\text { assistants to } \\
\text { promote } \\
\text { independent } \\
\text { behavior, } \\
\text { individualized } \\
\text { rehabilitation } \\
\text { goals, reductions } \\
\text { in post-concussion } \\
\text { symptoms and } \\
\text { social and } \\
\text { behavioral } \\
\text { functioning. }\end{array}$ & Practice Option & $\begin{array}{l}\text { Technology } \\
\text { interventions using } \\
\text { aspects that } \\
\text { children have } \\
\text { experience with can } \\
\text { improve self- } \\
\text { monitoring, } \\
\text { cognitive skills and } \\
\text { social participation. } \\
\text { Further } \\
\text { investigation of the } \\
\text { efficacy of } \\
\text { technology type it } \\
\text { needed. }\end{array}$ \\
\hline
\end{tabular}

